\title{
Experimental Study of Beeswax / Rice Husk Ash Phase Changes Material as Energy Storage in Concrete
}

\author{
Razali Thaib
}

\begin{abstract}
Buildings with lightweight concrete are currently used as a solution for mass housing construction which is relatively cheaper, although it does not provide indoor thermal comfort due to the use of this building material. Lightweight concrete building materials are able to store heat for a long time, so that at night the heat is released indoors. The combination of building materials and PCM is an efficient way to increase the storage capacity of thermal energy in building components. The purpose of this study was to determine the compressive strength of the concrete if the coarse aggregate (gravel) was replaced by part of the gravel material using the Phase Change Material of beeswax (beeswax) according to the required percentage starting from $0 \%, 5 \%, 10 \%, 15 \%$ and if the aggregate was fine. (Sand) is partially replaced by using Rice husk ash with various variations starting from $0 \%, 5 \%, 10 \%, 15 \%$. In addition, this utilization is a good alternative, because there will be a process of utilizing rice husk ash which was previously wasted while these items can be used or processed into additives to the concrete mixture.
\end{abstract}

Index Terms - concrete, phase change material, beeswax, rice husk ash, energy storage.

\section{INTRODUCTION}

The pattern of Indonesia's energy consumption in the residential sector for heating or cooling reaches $43 \%$, water heating $27 \%$, lighting $3.4 \%$, household appliances $26.6 \%$. As for the use of electrical energy, up to $50 \%$ of the total electricity demand is absorbed in the building sector, so the residential sector plays a major role in consuming electricity both for lighting, household appliances and space conditioning. Indonesia as a developing country will certainly move to improve the standard of living of its population, so the pattern of energy use for homes will be mostly used for the purposes of achieving comfort in space through the air conditioning system, lighting systems, lighting systems and water heaters. The energy consumption pattern for the commercial building sector reaches $50-60 \%$ for air conditioning systems, $30 \%$ for lighting and the rest for other machine tools [1].

Buildings with lightweight concrete are currently used as a solution for mass housing construction which is relatively cheaper, although it does not provide indoor thermal comfort due to the use of this building material. Lightweight concrete building materials are able to store heat for a long time, so that at night the heat is released in the room. Research on the energy efficiency of the building sector in Indonesia has so far only focused on the use of electricity but has never questioned energy efficiency through the selection and use of building materials.

Thermal energy can be stored and retrieved in the form of internal energy changes from materials as sensible heat, latent heat and thermo-chemical or a combination thereof [2]. In sensible heat storage, energy is stored by increasing the temperature of the material. This system takes advantage of the heat capacity and temperature changes of the material during the heat absorption and release process. The amount of energy stored by the system depends on the specific heat of the media, changes in temperature and the mass of the media used. However, sensible heat storage requires a large amount of mass and volume to achieve the desired level of thermal comfort. To solve the problem in sensible heat storage systems, research in the area of latent heat storage systems began in the 1940's. Latent heat storage works based on heat absorption or release when the storage material undergoes a phase change from solid to liquid or from liquid to gas or vice versa [3]. In a thermo-chemical system, the energy absorbed or released takes place during the process of changing molecular bonds due to chemical reactions and the processes that are completely reversible.

Among these techniques, latent heat storage utilizing PCM has attracted researchers for its advantages in high energy storage and small temperature changes. Latent heat storage can be achieved through the solid-solid, solid-liquid, solidgas and gas-liquid transformation phases [2]. However, solidliquid systems are economically attractive for use in thermal energy storage systems.

Most of the studies that have been carried out by many researchers use inorganic PCM as a heat storage material, because it has high latent heat enthalpy, good thermal conductivity, is non-flammable and cheap [4]-[6]. However, most of the inorganic PCM is corrosive, mostly metal, and has a decomposition phase [7], [8]. To overcome some of the problems inherent in inorganic PCM, a study was carried out on the use of organic PCM as a heat storage medium [9]-[11]. Organic PCM is generally chemically stable, non-corrosive, non-toxic and has a high latent heat enthalpy. However, for the use of organic PCM in buildings, it is necessary to select the phase change temperature in the human comfort zone, namely in the range $18-26^{\circ} \mathrm{C}$ [12]-[14].

The combination of building materials and PCM is an efficient way to increase the thermal energy storage capacity of building components. The incorporation technique with

Submitted on March 22, 2021.

Published on April 13, 2021.

Razali Thaib, Mechanical Engineering Department, Universitas Syiah Kuala,

Darussalam, Banda Aceh, Indonesia.

(e-mail: razalithaib@unsyiah.ac.id) 
the composite form PCM-encapsulation is the simplest, practical and economical method. and has attracted the interest of many researchers in the last decade [15]. However, several problems still need to be resolved in the development of composite PCM which has other stable forms: The use of eutetic-PCM for composite development has not provided

good results and limited information on the thermophysical properties of PCM [16], [17]. Many of the proposed PCMs have a melting temperature not at the thermal comfort temperature $\left(16-26^{\circ} \mathrm{C}\right)$ [18], [19]. Some researchers claim that the supporting materials for making composites are materials that are not commonly used as building materials [20], [21].

The purpose of this study was to determine the compressive strength of the concrete if the coarse aggregate (gravel) was replaced by part of the gravel material using the Phase Change Material of beeswax (beeswax) according to the required percentage starting from $0 \%, 5 \%, 10 \%, 15 \%$ and if the aggregate was fine. (Sand) is partially replaced by using Rice husk ash with various variations starting from $0 \%, 5 \%$, $10 \%, 15 \%$. In addition, this utilization is a good alternative, because there will be a process of utilizing rice husk ash which was previously wasted while these items can be used or processed into additives to the concrete mixture.

\section{MATERIALS AND METHODS}

The materials used in this research are:

- The cement used is Portland cement.

- Coarse aggregate in the form of 1.5 inch $(38.1 \mathrm{~mm})$ crushed stone purchased from the factory (asphalt mixing plane).

- Coarse Aggregate in the form of PCM (Beeswax).

- Fine aggregate in the form of rice husk ash taken from the burning of grain at the mill or rice mill.

- Fine aggregate in the form of good quality sand.

The concrete mixing method used in this study is the Indonesian National Standard Method SK.SNI.T-15-199003. The concrete compressive strength planning that is planned is $\mathrm{f}^{\prime} \mathrm{c}$ of $20 \mathrm{MPa}$.

The test object used was 24 cubes of concrete measuring $15 \times 15 \times 15 \mathrm{~cm}$. Curing is carried out so that the next hydration process is not disturbed. If this happens, the concrete will experience cracks due to rapid water loss. This treatment is not only intended to obtain high compressive strength of concrete but is also intended to improve the quality of concrete durability, water resistance, resistance to and dimensional stability. Treatment of the specimen is done by wetting it (putting fresh concrete in water). In this study, the test object used was a cube-shaped specimen measuring $15 \times 15 \times 15 \mathrm{~cm}$ concrete and testing was carried out at the age of 14 and 28 days.

\section{RESULT AND DISCUSSION}

Fine aggregate can be in the form of natural sand, processed sand or a combination of the two sands which can loosen the air in concrete. The size of the fine aggregate varies between No. 4 and No. 100 American Standard filters. For fine aggregate testing, it can be seen at the following stages:
Sieve Analysis aims to make the size distribution of fine aggregates and the division of grains (gradations) of an aggregate using a sieve. From the analysis carried out, the following results can be obtained:

TABLE I: Results OF THE HASLUS AgGREgAte SIEVE TEST

\begin{tabular}{ccccc}
\multicolumn{5}{c}{ TABLE I: RESULTS OF THE HASLUS AGGREGATE SIEVE TEST } \\
\hline Filter $(\mathrm{mm})$ & $\begin{array}{c}\text { Hold the } \\
\text { filter }\end{array}$ & $\begin{array}{c}\text { Hold on } \\
(\mathrm{gr})\end{array}$ & $\begin{array}{c}\text { Withheld } \\
(\%)\end{array}$ & $\begin{array}{c}\text { Passed } \\
(\%)\end{array}$ \\
\hline 3/8 $(9,52)$ & - & - & - & 100 \\
No. 4 $(4,75)$ & 33,90 & 33,90 & 1,84 & 98,16 \\
No. 8 $(2,36)$ & 93,10 & 127,00 & 6,88 & 93,12 \\
No. 16 $(1,10)$ & 176,90 & 303,90 & 16,48 & 83,52 \\
No. 30 $(0,50)$ & 390,10 & 694,00 & 37,62 & 62,38 \\
No. 50 $(0,27)$ & 858,30 & 1552,30 & 84,15 & 15,85 \\
No. 100 $(0,148)$ & 238,40 & 1790,70 & 97,08 & 2,92 \\
Pan & 53,90 & 1844,60 & 100 & 0 \\
\hline
\end{tabular}

Density Testing Testing is intended to determine the density (bulk), saturated surface dry specific gravity (SSD). From the results of the specific gravity test, the average density of SSD is 2.61 and it can be classified as a normal aggregate because the value is still within the allowable limit of 2.2-2.7. Water absorption (absorption) obtained from the test results is $1.35 \%$. This figure shows that the ability of the aggregate to absorb water from absolute dry to face dry saturation is $1.35 \%$ of the dry weight of the aggregate itself.

Water content examination aims to determine the aggregate moisture content by drying. The water content of the aggregate is the ratio between the weight of water contained in the aggregate and the dry aggregate. This moisture content value is used for water pressure correction for the adjusted concrete mix

Coarse aggregate is gravel as a result of natural disintegration of rock or in the form of crushed stone obtained from the stone crusher industry and has a grain size of between $5-40 \mathrm{~mm}$. Sieve analysis is to determine the grain size and grain composition of the aggregate. The results of the Coarse Aggregate Sieve Analysis Test are shown in Table II.

TABLE II: TEST RESUltS FOR COARSE AGGREGATE SIEVE

\begin{tabular}{ccccc}
\hline Filter $(\mathrm{mm})$ & $\begin{array}{c}\text { Hold the } \\
\text { filter }\end{array}$ & Hold on $(\mathrm{gr})$ & $\begin{array}{c}\text { Withheld } \\
(\%)\end{array}$ & Passed $(\%)$ \\
\hline $3 / 8(9,52)$ & - & - & - & 100 \\
No. 4 (4,75) & 33,90 & 33,90 & 1,84 & 98,16 \\
No. 8 (2,36) & 93,10 & 127,00 & 6,88 & 93,12 \\
No. 16 (1,10) & 176,90 & 303,90 & 16,48 & 83,52 \\
No. 30 (0,50) & 390,10 & 694,00 & 37,62 & 62,38 \\
No. 50 (0,27) & 858,30 & 1552,30 & 84,15 & 15,85 \\
No. 100 (0,148) & 238,40 & 1790,70 & 97,08 & 2,92 \\
Pan & 53,90 & 1844,60 & 100 & 0 \\
\hline
\end{tabular}

The slump test is carried out to determine the thickness of the concrete mix, which can describe the ease of workability of the concrete. Results of Normal Concrete Compressive Strength Testing.

TABLE III: THE RESUltS OF THE NORMAL CONCRETE COMPRESSIVE STRENGTH TEST

\begin{tabular}{cccccccc}
\hline & & \multicolumn{6}{c}{ Age of Normal Concrete } \\
\cline { 3 - 8 } No. & Description & \multicolumn{3}{c}{ 14 Days } & \multicolumn{3}{c}{ 28 Days } \\
\cline { 3 - 8 } & & I & II & III & I & II & III \\
\hline 1 & Slump (cm) & 11 & 11 & 11 & 11 & 11 & 11 \\
2 & $\begin{array}{c}\text { Concrete Weight } \\
(\text { gr) }\end{array}$ & 8050 & 8065 & 8095 & 7955 & 8055 & 8125 \\
& $\begin{array}{c}\text { Compressive } \\
3\end{array}$ & 17,31 & 18,44 & 19 & 23,52 & 22,58 & 20,69 \\
$\begin{array}{c}\text { Average Compressive } \\
\text { Strength (Mpa) }\end{array}$ & 18,25 & & & 22,26 & & \\
\hline
\end{tabular}


From the results of testing the compressive strength of normal concrete at the age of 14 and 28 days of concrete, there is an increase in the compressive strength shown in the graph of normal concrete compressive strength. At 28 days of concrete, the maximum compressive strength is $22.26 \mathrm{MPa}$.

From the test results the compressive strength of beeswax concrete and rice husk ash shown in Table 2 shows a decrease in compressive strength compared to normal concrete, the greater the percentage of additive beeswax material and rice husk ash, the lower the compressive strength obtained.

TABLE IV: COMPRESSIVE STRENGTH TEST RESUltS AFTER ADDING PCM + RICE HUSK ASH

\begin{tabular}{|c|c|c|c|c|c|c|c|}
\hline \multirow[t]{2}{*}{ No } & \multirow[t]{2}{*}{ Description } & \multicolumn{2}{|c|}{$\begin{array}{c}5 \% \text { PCM } \\
\text { (Beeswax + Rice } \\
\text { Husk Ash) } \\
\text { Concrete Age }\end{array}$} & \multicolumn{2}{|c|}{$\begin{array}{l}\text { 10\% PCM } \\
\text { (Beeswax } \\
\text { + Rice } \\
\text { Husk Ash) } \\
\text { Concrete } \\
\text { Age }\end{array}$} & \multicolumn{2}{|c|}{$\begin{array}{c}15 \% \text { PCM } \\
\text { (Beeswax + } \\
\text { Rice Husk } \\
\text { Ash) Concrete } \\
\text { Age }\end{array}$} \\
\hline & & 14 day & $\begin{array}{c}18 \\
\text { day }\end{array}$ & $\begin{array}{c}14 \\
\text { day }\end{array}$ & $\begin{array}{c}18 \\
\text { day }\end{array}$ & $\begin{array}{c}14 \\
\text { day }\end{array}$ & $\begin{array}{c}18 \\
\text { day }\end{array}$ \\
\hline 1 & $\begin{array}{c}\text { Average } \\
\text { Slump }(\mathrm{cm}) \\
\text { Average }\end{array}$ & 10,50 & 10,50 & 9,50 & 9,50 & 8,00 & 8,00 \\
\hline 2 & $\begin{array}{l}\text { Concrete } \\
\text { Weigh (gr) } \\
\text { Average }\end{array}$ & 7283 & 7336 & 6843 & 6869 & 6563 & 6602 \\
\hline 7 & $\begin{array}{l}\text { Compressive } \\
\text { Strength } \\
(\mathrm{MPa})\end{array}$ & 8,65 & 10,28 & 5,83 & 6,71 & 3,32 & 4,33 \\
\hline
\end{tabular}

From this research, the use of Beeswax and rice husk ash in the concrete mixture did not increase the compressive strength of the concrete. The results of the concrete compressive strength test in this study showed that the normal 28-day concrete compressive strength was $22.26 \mathrm{MPa}$, after finding coarse aggregate material with beeswax and rice husk ash, there was a decrease in the compressive strength of concrete, Beeswax and rice husk ash 5\% at 28 days of age shows the results of concrete strength of $10.28 \mathrm{MPa}$, Beeswax and $10 \%$ rice husk ash at the age of 28 days shows the results of the concrete compressive strength of $6.71 \mathrm{MPa}$, Beeswax and $15 \%$ rice husk ash at 28 days of age shows the results of concrete strength, $33 \mathrm{MPa}$.

The causes of the quality of the concrete not reaching its characteristics and not achieving the compressive strength of the plan are as follows:

- Because some of the ash of the rice husk is fine, so the concrete does not bind perfectly

- The sticky form of beeswax and fine rice husk ash are not suitable for mixing concrete materials.

\section{CONCLUSION}

From the research that has been done and the results of the discussion, it can be concluded that:

- Beeswax and rice husk ash are not suitable for use as a concrete mixture because the two materials cannot bind each other. And the compressive strength of concrete has significantly decreased, especially when compared to normal concrete.

- The normal 28-day concrete compressive strength is 22.26 $\mathrm{MPa}$, after replacing fine aggregate with beeswax and rice husk ash, there is a decrease in the compressive strength of concrete, Beeswax and rice husk ash $5 \%$ at the age of 28 days showing a concrete strength yield of $10.28 \mathrm{Mpa}$, Beeswax and $10 \%$ rice husk ash at the age of 28 days showed the results of the concrete compressive strength of $6.71 \mathrm{MPa}$, Beeswax and $15 \%$ rice husk ash at the age of 28 days showed the yield of concrete strength of 4.33 MPa.

- The mixture of $15 \%$ Beeswax diangka and rice husk ash is not suitable for use because it has decreased the compressive strength below the $4.33 \mathrm{MPa}$ brick wall compressive strength.

For further research development, Beeswax PCM and rice husk ash are not mixed at once. It is recommended for future research development using capsules (beeswax + rice husk ash put into capsules).

\section{REFERENCES}

[1] Dewan Energi Nasional, Outlook Energi Indonesia 2014. 2014.

[2] A. Pasupathy, R. Velraj, and R. V. Seeniraj, "Phase change materialbased building architecture for thermal management in residential and commercial establishments," Renew. Sustain. Energy Rev., vol. 12, no. 1, pp. 39-64, 2008.

[3] A. Sharma, V. V. Tyagi, C. R. Chen, and D. Buddhi, "Review on thermal energy storage with phase change materials and applications," Renew. Sustain. Energy Rev., vol. 13, no. 2, pp. 318-345, 2009.

[4] D. B. and D. F. C. D.W. HAWES, "Latent Heat Storage in Concrete," Sol. Energy Mater., vol. 19, pp. 335-348, 1989.

[5] D. W. Hawes, D. Banu, and D. Feldman, "Latent heat storage in concrete. II," Sol. Energy Mater., vol. 21, no. 1, pp. 61-80, 1990.

[6] D. W. Hawes, D. Feldman, and D. Banu, "Latent heat storage in building materials," Energy Build., vol. 20, no. 1, pp. 77-86, 1993.

[7] A. Gil, M. Medrano, I. Martorell, A. Lazaro, P. Dolado, B. Zalba, and L. F. Cabeza, "State of the art on high temperature thermal energy storage for power generation. Part 1-Concepts, materials and modellization," Renew. Sustain. Energy Rev., vol. 14, no. 1, pp. 31$55,2010$.

[8] R. Baetens, B. P. Jelle, and A. Gustavsen, "Phase change materials for building applications: A state-of-the-art review," Energy Build., vol 42, no. 9, pp. 1361-1368, 2010 .

[9] A. V. Sá, M. Azenha, H. De Sousa, and A. Samagaio, "Thermal enhancement of plastering mortars with Phase Change Materials: Experimental and numerical approach," Energy Build., vol. 49, pp. 16-27, 2012.

[10] N. Shukla, A. Fallahi, and J. Kosny, "Performance characterization of PCM impregnated gypsum board for building applications," Energy Procedia 30 ( 2012 ) 370 - 379 SHC, vol. 30, pp. 370-379, 2012.

[11] S. Ali, T. Yiu, S. A. Barbhuiya, and W. Xu, "Development of formstable composite phase change material by incorporation of dodecyl alcohol into ground granulated blast furnace slag," Energy Build., vol. 62, pp. 360-367, 2013.

[12] A. M. Khudhair and M. M. Farid, "A review on energy conservation in building applications with thermal storage by latent heat using phase change materials," Energy Convers. Manag., vol. 45, no. 2, pp. 263-275, 2004

[13] V. V. Tyagi and D. Buddhi, "PCM thermal storage in buildings: A state of art," Renew. Sustain. Energy Rev., vol. 11, no. 6, pp. 1146$1166,2007$.

[14] N. Soares, J. J. Costa, A. R. Gaspar, and P. Santos, "Review of passive PCM latent heat thermal energy storage systems towards buildings' energy efficiency," Energy Build., vol. 59, pp. 82-103, 2013.

[15] S. A. Memon, "Phase change materials integrated in building walls: A state of the art review," Renew. Sustain. Energy Rev., vol. 31, pp. 870 906, 2014.

[16] A. Sari and A. Karaipekli, "Fatty acid esters-based composite phase change materials for thermal energy storage in buildings," Appl. Therm. Eng., vol. 37, pp. 208-216, 2012.

[17] A. Sari and A. Karaipekli, "Preparation, thermal properties and thermal reliability of palmitic acid/expanded graphite composite as form-stable PCM for thermal energy storage," Sol. Energy Mater. Sol. Cells, vol. 93, no. 5, pp. 571-576, 2009

[18] E. Wang, X. Kong, X. Rong, C. Yao, H. Yang, and C. Qi, “A Study on a Novel Phase Change Material Panel Based on Tetradecanol/Lauric Acid/Expanded Perlite/Aluminium Powder for 
Building Heat Storage," Materials (Basel)., vol. 9, no. 11, p. 896, 2016.

[19] B. Xu and Z. Li, "Paraffin/diatomite composite phase change material incorporated cement-based composite for thermal energy storage," Appl. Energy, vol. 105, pp. 229-237, 2013.

[20] M. Amin, N. Putra, E. A. Kosasih, E. Prawiro, R. A. Luanto, and T. M. I. Mahlia, "Thermal properties of beeswax/graphene phase change material as energy storage for building applications," Appl. Therm. Eng., vol. 112, pp. 273-280, 2017.

[21] H. Cui, S. A. Memon, and R. Liu, "Development, mechanical properties and numerical simulation of macro encapsulated thermal energy storage concrete," Energy Build., vol. 96, pp. 162-174, 2015.

[22] A. I. Fernandez, M. Martnez, M. Segarra, I. Martorell, and L. F. Cabeza, "Selection of materials with potential in sensible thermal energy storage," Proc. 11th Int. Conf. Therm. energy storage. Stock. Sweden. Stock. Int. Fairs; 14-17 June, 2009., 2009.

[23] S. D. Sharma, H. Kitano, and K. Sagara, "Phase Change Materials for Low Temperature Solar Thermal Applications," Res. Rep. Fac. Eng. Mie Univ., vol. 29, pp. 31-64, 2004.

[24] I. Dincer and M. A. Rosen., "Thermal Energy Storage Systems And Applications, Second Edition," John Wiley and Sons, England, 2002.

[25] A. Castell, I. Martorell, M. Medrano, G. P??rez, and L. F. Cabeza, "Experimental study of using PCM in brick constructive solutions for passive cooling," Energy Build., vol. 42, no. 4, pp. 534-540, 2010.

[26] I. Mandilaras, M. Stamatiadou, D. Katsourinis, G. Zannis, and M. Founti, "Experimental thermal characterization of a Mediterranean residential building with PCM gypsum board walls," Build. Environ., vol. 61, pp. 93-103, 2013.

[27] Y. Zhang, G. Zhou, K. Lin, Q. Zhang, and H. Di, "Application of latent heat thermal energy storage in buildings: State-of-the-art and outlook," Build. Environ., vol. 42, no. 6, pp. 2197-2209, 2007.

[28] T. E. Alam, J. S. Dhau, D. Y. Goswami, and E. Stefanakos, "Macroencapsulation and characterization of phase change materials for latent heat thermal energy storage systems," Appl. Energy, vol. 154, no. September, pp. 92-101, 2015. 